\title{
EchoGéo
}

$13 \mid 2010$

Afrique, 50 ans d'indépendance : État et territoires

\section{South African cities and Globalization}

Céline Vacchiani-Marcuzzo

\section{(2) OpenEdition}

Journals

Édition électronique

URL : https://journals.openedition.org/echogeo/12047

DOI : 10.4000/echogeo.12047

ISSN : 1963-1197

\section{Éditeur}

Pôle de recherche pour l'organisation et la diffusion de l'information géographique (CNRS UMR 8586)

\section{Référence électronique}

Céline Vacchiani-Marcuzzo, «South African cities and Globalization », EchoGéo [En ligne], 13|2010, mis en ligne le 20 septembre 2010, consulté le 03 août 2021. URL : http://journals.openedition.org/ echogeo/12047 ; DOI : https://doi.org/10.4000/echogeo.12047

Ce document a été généré automatiquement le 3 août 2021

EchoGéo est mis à disposition selon les termes de la licence Creative Commons Attribution - Pas d'Utilisation Commerciale - Pas de Modification 4.0 International (CC BY-NC-ND) 


\title{
South African cities and Globalization
}

\author{
Céline Vacchiani-Marcuzzo
}

Illustration 1 - Centre des affaires, Le Cap

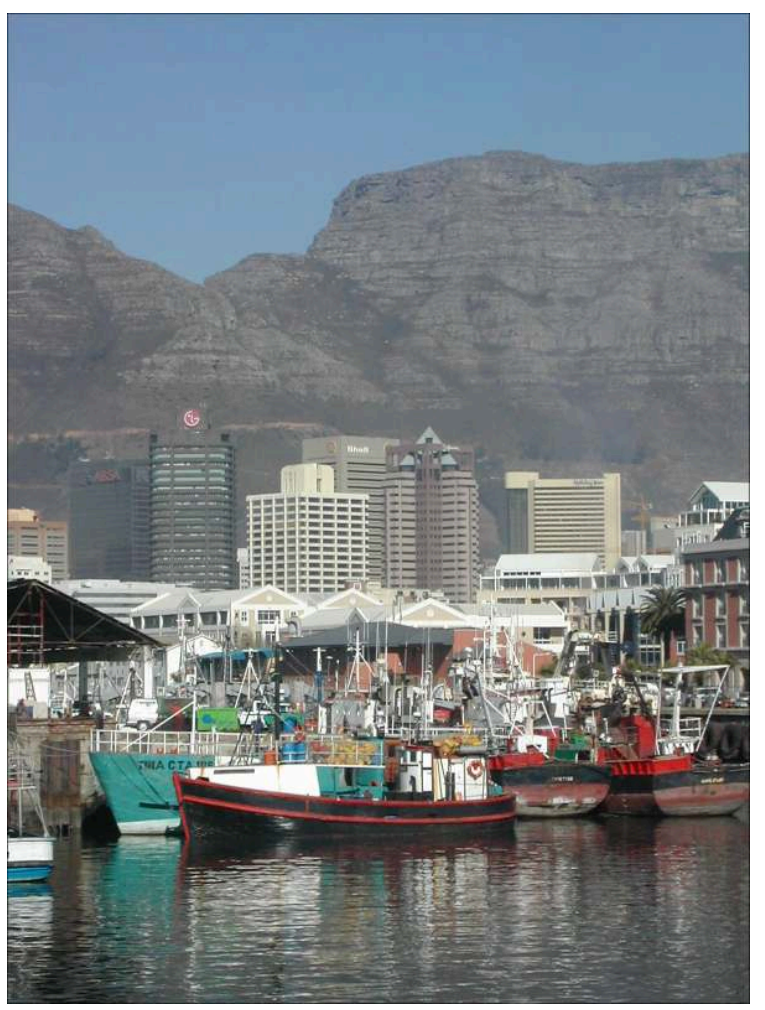

Auteur : Céline Vacchiani-Marcuzzo.

Born with colonial settlement patterns, the South-African urban system has experienced half a century of Apartheid. Under the effects of globalization, this urban system evolves as more developed urban systems and mature settlement patterns. This 
urbanization process (in the limits of functional urban agglomeration) makes South Africa one of the most advanced countries in Africa in terms of urban growth. The world-wide economical integration in the dynamics of the South-African urban system, by the means of direct investments and multinational firms settling implies different impacts and disruptions. Nowadays, despite of a long insertion of South Africa in international commercial flows, location strategies of foreign firms contribute, like everywhere else, to a strengthening of the metropolitan level of the hierarchy (especially Johannesburg but also Cape Town). They do not produce a noticeable urban specialization. A long-term analysis of investors' strategies nevertheless reveals emerging trends of diffusion and catching-up processes, especially on the coast, in coastal cities (cf. picture of Cape Town's CBD) and in their peripheries.

\section{BIBLIOGRAPHIE}

Giraut F., Vacchiani-MarcuzzoC., 2009. Territories and Urbanization in South Africa, Atlas and geohistorical information system (DYSTURB). Paris, IRD Editions, Collection Atlas et CD-Rom.

Bretagnolle A., Pumain D., Vacchiani-Marcuzzo C., 2009. The Organization of Urban Systems. In D. Lane, D. Pumain, S. Van der Leeuw, G. West (ed.), Complexity perspectives on innovation and social change, chapter 5, ISCOM, Springer, Methodos Series, p. 197-220.

Pumain D., Paulus F., Vacchiani-Marcuzzo C., 2009. Innovation Cycles and Urban Dynamics. In D. Lane, D. Pumain, S. Van der Leeuw, G. West (ed.), Complexity perspectives on innovation and social change, chapter 8, ISCOM, Springer, Methodos Series, p.237-260.

Vacchiani-Marcuzzo C., 2008. Quelle place pour le Cap dans la mondialisation ?: Stratégies spatiales des IDE et dynamique urbaine. In A. Dubresson, S. Jaglin (eds), Le Cap après l'apartheid, Gouvernance métropolitaine et changement urbain, Paris, Karthala.

Vacchiani-Marcuzzo C., 2005. Mondialisation et systèmes de villes : les entreprises étrangères et l'évolution des agglomérations sud-africaines. Thèse de doctorat nouveau régime, Université Paris 1 , $360 \mathrm{p}$.

\section{AUTEUR}

\section{CÉLINE VACCHIANI-MARCUZZO}

Université de Reims, UMR 8504 Géographie-cités, vacchiani@parisgeo.cnrs.fr 